\title{
Regulation and Taxation of the Financial Markets
}

\author{
by \\ Wolfgang SCHÖN*
}

The financial crisis has generated a high degree of legislative activity both in the area of substantive and procedural financial regulation and in the area of taxation of the financial sector. This article explores criteria for legislative choice (in particular for the European Union) when a given target can be addressed both by regulatory means and by fiscal burdens. Major examples include the (1) choice between capital requirements for financial institutions and the introduction of bank levies, (2) substantive constraints for executive compensation versus a "bonus tax", and (3) the relationship between the existing European regulatory regime of financial markets and the current project of a "financial transaction tax". While bank levies can play a meaningful role alongside capital requirements, both the "bonus tax" and the "financial transaction tax" seem less attractive than alternative regulatory options.

Table of Contents

ECFR 2016, 424-452

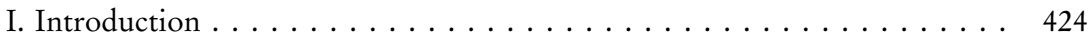

II. Fundamentals . . . . . . . . . . . . . . . . . . . . . . . . . 430

1. Permission and Prohibition versus Pricing . . . . . . . . . . . . . 430

2. Raising Revenue versus Regulating Risk and Rewards . . . . . . . . 431

3. Quantities versus Prices: The Information Problem . . . . . . . . . . . 432

4. Interim Result . . . . . . . . . . . . . . . . . . 435

5. General Tax Measures . . . . . . . . . . . . . . . . 435

III. Capital Requirements and Bank Levies . . . . . . . . . . . . . . . . . . 436

IV. Executive Pay and Bonus Taxation . . . . . . . . . . . . . . . . 443

V. Regulating and Taxing Financial Transactions. . . . . . . . . . . . . . . 448

VI. The Political Economy of the Choice between Regulation and Taxation . . 451

VII. Conclusions . . . . . . . . . . . . . . . . . . . . . . . 452

* Director, Max Planck Institute for Tax Law and Public Finance, Munich, and Honorary Professor at Munich University; this article is based on a lecture given at Tübingen University in November 2015 at the Symposium on the European Capital Market Union celebrating the $75^{\text {th }}$ birthday of Klaus Jürgen Hopt. 


\section{Introduction}

Since the outbreak of the financial crisis in 2007 , legislators around the world have produced an enormous regulatory output aiming at tighter control of economic actors, in particular banks and other professional financial market operators, with a view on increased protection of private investors. Notable legislation includes the "Basel III Accord" on capital requirements for banks", the "Dodd Frank Wallstreet Reform and Consumer Protection Act" 2 in the United States and a bewildering array of regulations, directives, delegated regulations and intergovernmental agreements at the level of the European Union ${ }^{3}$. Recent arrivals from Brussels include the Capital Requirements Regulation ${ }^{4}$ and the CRD IV Directive ${ }^{5}$ issued in 2013 as well as a host of legislation in 2014 setting up a European resolution regime for credit institutions ${ }^{6}$. Overshadowing domestic and international legislation is the political consensus at the level of the G20 and the work of its Financial Stability Board 7 as well as the authoritative publications of the Basel Committee on Banking Supervision $^{8}$. In terms of legal technique, financial regulation under these enactments largely affects supervisory law for financial markets as well as the

1 Basel Committee on Banking Supervision, Basel III: A global regulatory framework for more resilient banks and banking systems, December 2010.

2 111th Congress Public Law 203.

3 Elke Gurlit/Isabel Schnabel, The New Actors of Macroprudential Supervision in Germany and Europe - A Critical Evaluation, 27 Zeitschrift für Bankrecht und Bankwirtschaft (2015) p.349-362.

4 Regulation (EU) No.575/2013 of the European Parliament and of the Council of $26^{\text {th }}$ June 2013 on prudential requirements for credit institutions and investment firms and amending Regulation (EU) No. 648/2012, O.J. L 176/1 of 27th June 2013.

5 Directive 2013/36/EU of the European Parliament and of the Council of $26^{\text {th }}$ June 2013 on access to the activity of credit institutions and the prudential supervision of credit institutions and investment firms, amending Directive 2002/87/EC and repealing Directives 2006/48/EC and 2006/49/EC, O.J. L 176/338 of 27th June 2013.

6 Directive 2014/59/EU of the European Parliament and of the Council of 15th May 2014 establishing a framework for the recovery and resolution of credit institutions and investment firms and amending Council Directive 82/891/EEC, and Directives 2001/24/ED, 2002/47/EC, 2004/25/EC, 2005/36/EC, 2011/35/EU, 2012/30/EU, and Regulations (EU) No. 1093/2010 and (EU) No.648/2012 of the European Parliament and of the Council, O.J. L 173/190 of $12^{\text {th }}$ June 2014; Regulation (EU) No. 806/2014 of the European Parliament and of the Council of 15th July 2014 establishing uniform rules and a uniform procedure for the resolution of credit institutions and certain investment firms in the framework of a Single Resolution Mechanism and a Single Resolution Fund and amending Regulation (EU) No. 1093/2010, O.J. L 225/1 of 30th July 2014.

7 See recently: Financial Stability Board - The Chairman, To G20 Leaders: Financial Reform - Achieving and Sustaining Resilience for All, 9th November 2015.

8 See recently: Basel Committee on Banking Supervision, Ninth progress report on adoption of the Basel regulatory framework, October 2015. 
corporate governance of banks - a topic, which Klaus Hopt has profoundly examined in two seminal papers published in $2010^{9}$ and $2013^{10}$ respectively.

This major evolution in the world of regulation has been accompanied by a parallel development in the world of taxation. Taxation of the financial sector was first tabled in a comprehensive fashion at the level of the G20 at their Pittsburgh Summit in 2009 when political leaders asked the International Monetary Fund (IMF) to

"prepare a report for our next meeting with regard to the range of options countries have adopted or are considering as to bow the financial sector could make a fair and substantial contribution toward paying for any burden associated with government interventions to repair the banking system"11

While this wording clearly and simply aimed at the extraction of public revenue from the financial sector to make up for the damage done so far, the G20 ministers and central bank governors who met in April 2010 took a more sophisticated stance, adding regulatory goals to the brief. They called upon the IMF to undertake

"further work on options to ensure domestic financial institutions bear the burden of any extraordinary government interventions where they occur, address their excessive risk taking and help promote a level playing field, taking into consideration individual country's circumstances. ${ }^{12}$

Under this heading, the IMF put forward its widely influential 2010 report on "A Fair and Substantial Contribution by the Financial Sector" ${ }^{13}$ which laid out three major options for fiscal interventions in the financial sector:

- A "financial stability contribution" largely along the lines of "bank levies" previously introduced in several countries ${ }^{14}$. The most prominent example

9 Klaus-Jürgen Hopt, Corporate Governance of Banks after the Financial Crisis, in: Eddy Wymeersch/Klaus Jürgen Hopt/Guido Ferrarini (Ed.), Financial Regulation and Supervision: A Post-Crisis Analysis (OUP) 2012, p.337-367.

10 Klaus Jürgen Hopt, Corporate Governance of Banks and other Financial Institutions after the Financial Crisis, 13 Journal of Corporate Law Studies (2013) p.219-253.

11 G20 Leaders Statement: The Pittsburgh Summit, September 24-25, 2009, Pittsburgh, A Framework for Strong, Sustainable, and Balanced Growth, para 16.

12 Meeting of Finance Ministers and Central Bank Governors, 23rd April 2010, Communiqué, para 4.

13 International Monetary Fund, A Fair and Substantial Contribution by the Financial Sector: Final Report for the G-20, June 2010; Michael Keen, The Taxation and Regulation of Banks, IMF Working Paper (WP/11/206), 2011.

14 International Monetary Fund supra note 13, para 13 et seq.; for the UK bank levy see: Michael Devereux, Will the bank levy meet its objectives?, British Tax Review (2010) p.33-39; Liesl Fichardt, Taxing the Financial Sector: Bank Levies in the United King- 
for such a bank levy has recently been established for the Eurozone under the European single resolution regime as banks from all participating countries have to pay fees transferred to and centrally administered by a single resolution fund ${ }^{15}$.

- A "financial activities tax" (FAT) on excessive profits derived from excessive risk-taking ${ }^{16}$. While the IMF and leading academics ${ }^{17}$ strongly proposed action in this direction, they did not meet with wide support politically. Only in a few countries, small remnants of the FAT can be found in mostly temporary - attempts to establish a special charge on bankers' bonuses ${ }^{18}$ and in the very recent introduction of a "corporation tax surcharge" on bank profits by the UK Government ${ }^{19}$.

- The most prominent of these three archetypes of financial sector taxation is the "financial transaction tax" (FTT) which the IMF itself in its study clearly dismissed as overly blunt and misguided ${ }^{20}$. Nevertheless, a directive on the FTT was proposed by the European Commission in 2011 for being the standard for the whole European Union ${ }^{21}$; following rejection by the

dom, in: Otto Marres/Dennis Weber(Ed.), Taxing the Financial Sector: Financial Taxes, Bank Levies and More (IBFD 2012) p.71-86.

15 Art. 99 et seq. Directive 2014/59/EU supra note 5; Art. 67 Regulation (EU) No. 806/ 2014 supra note 4; Lucia OrszaghovalMartina Miskova, Financial Contributions and Bank Fees in the Banking Union, 23 Rocnik (2015) p.13-18; as to the political background of the creation of the Single Resolution Mechanism see: David Howarth/Lucia Quaglia, The Steep Road to European Banking Union: Constructing the Single Resolution Mechanism, 52 Journal of Common Market Studies (2014) p.125-140.

16 International Monetary Fund supra note 13 para 32 et seq.

17 Michael P. Devereux, New Bank Taxes: Why and What Will Be the Effects?, in: Ruud de Mooij/Gaetan Nicodème (Ed.), Taxation and Regulation of the Financial Sector (MIT 2014) p.25 et seq. (at 48); Daniel N. Shaviro, The Financial Transaction Tax vs the Financial Activities Tax, in: Otto Marres/Dennis Weber (Ed.), Taxing the Financial Sector: Financial Taxes, Bank Levies and More (IBFD 2012), p.165-202 (at 176 et seq.); Thomas Hemmelgarn/Gaetan Nicodème, Can Tax Policy Help to Prevent the Financial Crisis?, in: Julian S. Alworth/Giampaolo Arachi (Ed.), Taxation and the Financial Crisis (OUP 2012) p.116-147 (at p.122 et seq.).

18 For a comparative view see: $I M F$ supra note 13, para 9 and Appendix 2, C/D/E; Holger Fleischer, Zur Regulierung der Vorstandsvergütung durch das Steuerrecht, Der Betrieb (2010) p.601-607; Paolo Ludovici/Mario Tenore, Financial Activities Tax (FAT) in Italy, in: Otto Marres/Dennis Weber (Ed.), Taxing the Financial Sector: Financial Taxes, Bank Levies and More (IBFD 2012), p.87-96.

19 Her Majesty's Treasury, Summer Budget 2015, para 1.201-1.203; as to the impact of the new tax on the financial markets see: Competition and Markets Authority, Retail banking market investigation: Corporation tax surcharge and bank levy, 26 ${ }^{\text {th }}$ February 2016.

20 International Monetary Fund supra note 13 para 28 et seq.

21 Proposal for a Council Directive on a common system of financial transaction tax and amending Directive 2008/7/EC of 28 ${ }^{\text {th }}$ August 2011 COM(2011)594 final; Oskar Hen- 
United Kingdom and some other Member States, the FTT is still on the political agenda and currently under examination for being introduced on the basis of the "enhanced cooperation" procedure among a limited group of Member States 22 .

These three major types of financial sector taxation do not only aim at raising revenue. They are meant to fulfill regulatory functions, to correct market failure and to steer individual behavior towards efficient outcomes ${ }^{23}$. Both lawyers and economists attempt to justify such types of taxes as "Pigouvian" in the tradition of Arthur Pigou's concept of taxation as a means to "internalize" social cost at the level of the economic actor causing the social harm ${ }^{24}$. But this legislative intention immediately brings up the question of how to reconcile regulatory action which consists of new supervisory mechanisms and additional corporate governance rules on the one hand with burdensome corrective taxation on the other hand. Mike Devereux from Oxford University has put it this way ${ }^{25}$ : Either tax law and regulatory law set incentives for identical behavior - then one of the instruments seems to be superfluous. Or tax law and regulatory law set incentives in different directions - then we might have a case of contradicting legislation which requires adjustments along one of the two dimensions. Multiple instruments, as has been noticed,

kow, The FTT Proposal - An Overview of Legal Issues Arising, in: Otto Marres/Dennis Weber (Ed.), Taxing the Financial Sector: Financial Taxes, Bank Levies and More (IBFD 2012), p.1-24.

22 Proposal for a Council Directive implementing enhanced cooperation in the area of financial transaction tax of 14th February 2013 COM(2013)71 final; for a critical assessment see: Giorgia Maffini/John Vella, Evidence-based policy making? The Commissions's Proposal for an FTT, OUCBT Working paper series, WT15/15, 2015; financial transaction taxes in place or considered in the Member States of the European Union are discussed by: Gaetan Nicodème/Thomas Hemmelgarn/Bogdan-Alexandru Tasnadil Pol Vermote, Financial Transaction Taxes in the European Union, 69 National Tax Journal (2016) p.217-240; the legal framework of "enhanced cooperation" is analyzed by Federico Fabbrini, Taxing and Spending in the Euro Zone: Legal and Political Challenges to the Adoption of the Financial Transaction Tax, 39 European Law Review (2014) p.155-175; Joachim Englisch/John Vella/Anzhela Yevgenyeva, The Financial Transaction Tax Proposal Under the Enhanced Cooperation Procedure: Legal and Procedural Considerations, British Tax Review (2010) p.223-259.

$23 I M F$ supra note 13, para 15 and Appendix 3.

24 Arthur Cecil Pigou, The Economics of Welfare, $4^{\text {th }}$ Ed., 1932 (reprint 1952) p.223 et seq.; for a recent plea by lawyers in favor of corrective taxation see: Jonathan S. Masur/Eric A. Posner, Towards a Pigouvian State, 164 University of Pennsylvania Law Review (2015) p.93-147; see also: Douglas A. Shackelford/Daniel N. Shaviro/Joel Slemrod, Taxation and the Financial Sector, 63 National Tax Journal (2010) p.781-806; Carlo Garbarino/Giulio Allevato, The Global Architecture of Financial Regulatory Taxes, 36 Michigan Journal of International Law (2015) p.603-648.

25 Devereux supra note 17, p.43 et seq.; Devereux supra note 14, p.37 et seq. 
sometimes simply reflect "the temptation of politicians to "fix everything"'26 both by taxing and by regulating a specific target ${ }^{27}$.

Given the enormous amount of literature on both the regulation and the taxation of the financial sector, it is striking that the interaction between these two areas of legislation has rarely been discussed ${ }^{28}$. This is particularly true for the political debate where the different administrative and legislative units entrusted with regulation and taxation respectively do not seem to talk to each other very often. Among academics, mostly economists have addressed the issue $^{29}$ while legal scholars have been largely mute ${ }^{30}$. Taking a closer look, this case is a prominent example of the well-known debate on regulatory choice giving advice to the legislator which instrument from the "toolbox" is best for which purpose. Klaus Hopt has expressed his credo in this debate clear enough: Form follows function! is the guiding theme which he has translated from aesthetics into law $^{31}$. Following his advice, this article embarks on the functional approach in order to decide on the merits of regulation and taxation of

26 Cameron Hepburn, Regulation by Prices, Quantities, or Both: A Review of Instrument Choice, 22 Oxford Review of Economic Policy (2006) p.226-247 (231).

27 For an example of "regulatory collision" within the regulatory framework of the financial sector see: Colleen M. Baker, Regulatory reforms and unintended collisions: the case of the Volcker Rule and the over-the-counter derivative markets, 10 Capital Markets Law Journal (2015) p.433-446.

28 A related issue concerns the joint use of corrective taxation and liability rules (Steven Shavell, Corrective Taxation versus Liability, 101 American Economic Review: Papers \& Proceedings (2011) p.273-276; Steven Shavell, Corrective Taxation versus Liability as a Solution to the Problem of Harmful Externalities, 54 Journal of Law and Economics (2011) p.249-266 (at 263 et seq.); Michelle J. White/Donald Wittman, A Comparison of Taxes, Regulation, and Liability Rules under Imperfect Information, 12 Journal of Legal Studies (1983) p.413-425).

$29 I M F$ supra note 13, Appendix 3; Keen supra note 13; Enrico Perotti/Javier Suarez, A Pigovian Approach to Liquidity Regulation, 7 International Journal of Central Banking (2011) p.3-41; Julian S. Alworth/Giampaolo Arachi (Ed.), Taxation and the Financial Crisis (OUP) 2012; Rund de Mooij/Gaetan Nicodème (Ed.), Taxation and Regulation of the Financial Sector (MIT Press), 2014; Saijid M. Chaudbry/Andrew W. Mullineux/ Natasha Agarwal (Ed.), Balancing the Regulation and Taxation of Banking (Elgar: Northampton), 2015.

30 But see: Alexander Hellgardt, Comparing Apples and Oranges? Public, Private, Tax, and Criminal Law Instruments in Financial Markets Regulation, and John Vella, Regulatory Choice: Observations on the Recent Experience with Corrective Taxes in the Financial Sector, both articles in: Wolf-Georg Ringe/Peter Michael Huber (Ed.), Legal Challenges in the Global Financial Crisis: Bail-outs, the Euro and Regulation (Bloomsbury) 2015, p.157-176 and p.177-186; Tim Edgar, Corrective Taxation, Leverage, and Compensation in a Bloated Financial Sector, 33 Virginia Tax Review (2014) p.393-428; for an interdisciplinary perspective see: Shackelford/Shaviro/Slemrod supra note 24, p.791 et seq.

31 Klaus Jürgen Hopt, Auf dem Weg zu einer neuen europäischen und internationalen 
the financial sector. This approach is also in line with the recently issued "Action Plan" of the European Commission on the "Capital Markets Union" where the Commission announces a

"comprehensive review, in parallel with this Action Plan, of the cumulative impact and coherence of the financial legislation adopted over the past years and the numerous interactions between them, (as) there is a risk that their collective impact may have some unintended consequences, which may not be picked up within individual sectoral reviews" $"$.

In order to set this in motion we shall focus on three different issues which are each central to the debate:

- the choice between regulatory capital requirements and a bank levy when it comes to creditor protection and the fight against excessive risk taken by banks;

- the choice between supervisory restrictions for executive pay versus a bonus tax - both meant to fight inefficient incentives for bank managers;

- the choice between substantive directives and regulations on market behavior, financial services and the like versus the financial transaction tax with regard to ensuring the credibility and stability of capital markets.

\section{Fundamentals}

\section{Permission and Prohibition versus Pricing}

When it comes to the assessment of different legislative tools, legal scholars show a tendency to make distinctions along the lines of legality versus illegality $^{33}$. This feeds into a view which considers regulation to work with a binary code of "permission versus prohibition" while taxation simply sets public

Finanzmarktarchitektur, 12 Neue Zeitschrift für Gesellschaftsrecht (2009) p.1401-1408 (at 1402).

32 European Commission, Communication from the Commission to the European Parliament, the Council, the European Economic and Social Committee and the Committee of the Regions, Action Plan on Building a Capital Markets Union (COM(2015)468 final) para 3.4; for a critical assessment see: Wolf-Georg Ringe, Capital Markets Union for Europe: a commitment to the Single Market of 28, 9 Law and Financial Markets Review (2015) p.5-7.

33 Christoph Trzaskalik, Inwieweit ist die Verfolgung ökonomischer, ökologischer und anderer öffentlicher Zwecke durch Instrumente des Abgabenrechts zu empfehlen?, Gutachten E für den 63. Deutschen Juristentag (C.H.Beck) 2000, at p.E 16. 
prices for a given behavior without any positive or negative assessment of the activity as such.

Taking a closer look and leaving aside any moral or reputational concerns or tools (like "corporate shaming" ${ }^{34}$ ), this distinction is less obvious. On the one hand it is clear that taxation is normally not intended to fully wipe out certain activities and that it only assigns a (moderate) extra cost to a given behavior. But it is easy to devise a confiscatory tax, which aims so high that it renders the taxed activity more or less meaningless, thus functioning like an outright prohibition. On the other hand it is evident that one can model each regulatory prohibition as a highly progressive tax which applies a zero rate until you cross a certain limit (e.g. a minimum capital requirement or an upper ceiling for executive pay), the "tax" being the amount of fines, penalties, profit disgorgements and damage claims an offender has to face in the case he transgresses the borderline between the permitted and the prohibited behavior. Apart from quite severe cases, which lead to professional disqualification or even imprisonment, all adverse consequences of being caught breaking the law can be expressed in monetary terms - like a tax. Both regulation and taxation therefore simply lead to an increase in the cost attached to a certain economic event albeit with a quite different design of the cost function.

\section{Raising Revenue versus Regulating Risk and Rewards}

Another commonly held belief refers to the effect of legislative tools on the borderline between the private sector and the public sector. While the use of tax instruments is associated with the transfer of private funds to the public coffers, instruments in the area of private law - e.g. a corporate governance framework - rather seem to redistribute wealth and income between private parties. The latter also seems to hold true for supervisory activities which do not end up in major financial reallocations to the detriment of private economic actors. Nevertheless, a closer view reveals the need for some further distinctions ${ }^{35}$ :

- The first glance is devoted to taxation: A bank levy might go the general budget of a state like any mainstream tax: but it might as well be used to set up a resolution fund dedicated for bank bailouts ${ }^{36}$. This keeps the money in the financial market system but not in the hands of individual private

34 David A. Skeel, Shaming in Corporate Law, 149 University of Pennsylvania Law Review (2001) p.1811-1868.

35 Brian D. Galle, Tax, Command ... or Nudge? Evaluating the New Regulation, 92 Texas Law Review (2014) p.837-894 (849 et seq. and 869 et seq.).

$36 I M F$ supra note 13 para 22 et seq. 
actors. This middle ground between private market and public budget brings about specific benefits and drawbacks which we will go into at a later stage.

- There are similar sophistications necessary when regulatory action has to be designed ${ }^{37}$ : A legislator might choose to grant permits and licenses for free - then all the money stays within the ambit of the private markets - or the regulator licenses these rights against consideration as we have seen for broadband telecommunication licenses and for environmental permits in the cap-and-trade market. A financial regulator might therefore think of simply selling a given number of bank licenses to the highest bidders - thus creating an up-front financial cushion in the public domain, weeding out inefficiently prepared market participants and making bankers pay for their rent-seeking activities.

Irrespective of these budgetary consequences, the primary aspect both for taxation and regulation remains the corrective goal, i.e. the legislative intention to interfere with the economic activities of private economic actors. And insofar both regulation and taxation carry the same agenda. They are meant to increase market efficiency by countering inefficient incentives, addressing market failures and guiding private decision-making towards equilibrium where social welfare is improved as far as possible. But any misguided provisions on corporate governance, bank supervision or financial market taxation will entail excess burdens, so-called "deadweight losses" which signal inefficient behavior and damage social welfare without showing up in the public budget. The choice of legislative tools: either legislative regulation or corrective taxation is primarily concerned with these "deadweight losses" and to a less extent with the income and redistribution outcomes of the payments effected to the public budget.

\section{Quantities versus Prices: The Information Problem}

Against this background, the economic analysis of financial market taxation has been largely built on an earlier debate which took off in the 1970s, i.e. the economic analysis of environmental legislation ${ }^{38}$. Just like eco-taxes are meant to increase the cost of polluting air and water, thus internalizing the social costs affecting the environment, financial sector taxation is meant to fight excessive risk taking which imposes negative externalities on society at large, in particular

37 Hepburn supra note 26, p.236.

38 For a recent account of the merits of corrective taxation for environmental policy see: N. Gregory Mankiwe, Smart Taxes: An Open Invitation to Join the Pigou Club, 35 Eastern Economic Journal (2009) p.14-23. 
when banks which are "too big to fail" have to be bailed out with public money. In academic work on environmental taxation, the choice between regulation and taxation has been broken down to a choice between "quantities" and "prices", meaning that by regulation you allocate certain "quantities" to certain economic actors (e. g. you distribute a limited number of pollution permits) while by taxation you increase the price for pollution irrespective of the amount of pollution that actually happens ${ }^{39}$. It may look somewhat far-fetched that recent economic research on financial markets models regulation as the allocation of "quantities" to financial actors as well - this would imply that the setting of capital requirements or the implementation of corporate governance constraints can be understood as granting a bank the permission to emit a certain amount of dangerous risk to the market. A main difference lies in the fact that unlike for carbon dioxide emissions there is no fixed stock of banking permits that can be repartitioned across the whole (global) economy. Nevertheless there is one major lesson that can be learned from this example and this debate:

In a seminal article from $1974^{40}$, Martin Weitzman from the MIT highlighted, that the choice between quantities and prices does not play a role when the legislator is fully informed about the state of the world and all possible outcomes ${ }^{41}$. In such a mode of full knowledge it will be easy for the legislator to enact laws either in the field of regulation or in the area of taxation which will have an identical targeted effect on the behavior or private actors and which will do away with negative externalities or other sources of inefficiency right away. The choice between regulation and taxation comes up when - as always in real life - the legislator is not fully informed about the size of the potential harm, the amount of potential benefits of legislation and the efficiency gains and losses, which have to be reckoned with ${ }^{42}$.

In this state of partial information a well-advised legislator will try to find out whether regulation or taxation is better equipped to address the "known unknowns" as well as the "unknown unknowns" existing in the real world. For the choice between prices and quantities Weitzman himself reached the conclusion that the answer depends on whether the harm for social welfare seems to follow a gradually rising curve or whether there is a relatively clear focal point where the curve suffers a "kink", i.e. where the harm changes direction dramatically for the better or for the worse ${ }^{43}$. If the harms follow a gradually rising curve it might be advisable to use a corrective tax which incrementally raises the price for externalities in order to reach a stable state of efficiency.

39 For a review of the literature see: Cameron Hepburn supra note 26 at p.229 et seq.

40 Martin Weitzman, Prices vs. Quantities, Review of Economic Studies (1970) p.477-491.

$41 I M F$ supra note 13, p.12 Box 2 and Appendix 3, p.50 et seq.

42 Weitzman supra note 40, p.481.

43 Weitzman supra note 40, p.485. 
Environmental taxation for carbon dioxide emissions largely follows this approach. But if the curve shows a dramatic "kink" at a certain focal point it seems better to address that focal point and to limit behavior by strict regulation. A clear example is water pollution. If a gradual increase in contaminants can result in a sudden death of the whole lake, you will not simply levy a linear tax on pollution - you will clearly prefer a hard-and-fast regulation, which allocates severe (progressive) sanctions and even criminal punishment to any transgression of the ecological limit.

Kaplow/Shavell have rejected this distinction which refers to the shape of the social benefit/harm curve ${ }^{44}$. They have pointed out that Weitzman's result is based on the assumption that corrective taxation generally applies a linear tax rate (which follows the gradual increase of social cost effected by the harmful activity in question). Contrary to this, a non-linear tax would easily emulate the effects of quantity regulation in the case of a "kinked" social cost curve. But this is only true if the regulator - in the light of imminent harm - can afford to let private actors decide - in the light of their private benefits - whether or not they are willing to pay the price for harmful behavior. Otherwise the regulator will have to end up with an extraordinarily high non-linear tax rate that amounts to an outright prohibition (if the level of activity crosses a certain limit). As the regulator rarely knows the shape of the private benefit curve it seems easier to go for "command and control" in cases when violations have to be prohibited "at all cost".

Last but not least the "information problem" comes up again when there is a high degree of heterogeneity across private actors with regard to the social cost inflicted by a given behavior. In a recent article, Victor Fleischer puts forward the example of a "gun tax" meant to curb proliferation of weapons in the United States ${ }^{45}$. As social harm differs hugely depending on whether guns are owned by law-abiding citizens or by criminals, it is next to impossible to design a tax right on target. Shall people file tax returns ticking boxes depending on their willingness to comply with the law? In particular in regulatory fields where the size of social harm critically depends on the level of individual "care" taken by private actors to avoid this harm, the ensuing variation of private behavior cannot practically be monitored by the tax authorities ${ }^{46}$. For such a situation, "command-and-control" regulation or liabil-

44 Louis Kaplow/Steven Shavell, On the Superiority of Corrective Taxes to Quantity Regulation, 4 American Law and Economics Review (2002) p.1 et seq.; Devereux supra note 17, p.42 et seq.

45 Victor Fleischer, Curb Your Enthusiasm for Pigovian Taxes, 68 Vanderbilt Law Review (2015) p.1673-1713 (1677 et seq.).

46 Shavell supra note 28 (JLE) p. 250 et seq.; Hellgardt supra note 30 , at p.163 concerning sanctions for unsuitable investment advice. 
ity rules should be regarded as superior to corrective taxation. This test has to be applied as well with regard to financial sector taxation as "there is (in this sector) no single activity whose aggregate sum equals expected harm" 4 .

\section{Interim Result}

The - rather general - interim result can be described as follows: When the legislature has to decide whether to apply regulatory of fiscal tools to remedy social welfare losses, it has to take into account three features:

- the delineation between the private sector and the public sector: to what extent does it make sense to transfer funds to the public budget?

- the curvature of the social cost function: do we perceive a clear tilting point which makes it advisable to set substantive limitations at a certain point?

- the heterogeneity of the social cost function depending on individual behavior: does it make sense to apply a common (linear or non-linear) tax rate equally to a given set of private actors or activities?

\section{General Tax Measures}

Before we discuss legislative options of taxation versus regulation of the financial markets in more detail one should exclude one major issue from this exercise. There is a broad debate in the literature as to the extent to which general features of the taxation of income and consumption have contributed to the financial crisis in the first place. A lot of blame is put on two potentially harmful elements of the current tax system:

- In the first place, the deductibility of interest payments to creditors as opposed to the non-deductibility of dividends paid to shareholders is regarded as a "debt bias" which reinforces the general trend for banks to drive debt leverage beyond the efficient mix of funds recommended for the banking business ${ }^{48}$. This view has also been taken by the European Com-

47 Shackelford/Shaviro/Slemrod supra note 24, p.792

48 Michael Keen/Rund de Mooij, Debt, Taxes, and Banks, IMF Working Paper (WP/12/ 48); Michael Keen/Alexander Klemm/Victoria Perry, Culprit, Accomplice, or Bystander? Tax Policy and the Shaping of the Crisis, in: Julian S. Alworth/Giampaolo Arachi (Ed.), Taxation and the Financial Crisis (OUP) 2012, p.28 et seq. (at 30 et seq.); Daniel $N$. Shaviro, Income Tax Implications of the Financial Crisis, in: Julian S. Alworth/ Giampaolo Arachi (Ed.), Taxation and the Financial Crisis (OUP) 2012, p.174 et seq. (at 176 et seq.); Thomas Hemmelgarn/Daniel Teichmann, Tax reforms and capital structure of banks, European Commission Taxation Papers, Working Paper 37-2013, 2013; 
mission, most recently in its "Action Plan on Building a Capital Markets Union"49.

- In the second place, the exemption of financial services from the Value Added Tax is perceived as a wide-reaching tax subsidy for banks, increasing returns to risk-taking and contributing to an unsound extension of banking activities at large ${ }^{50}$.

It should be clear that a discussion of these two points would require a major analysis of income taxation and consumption taxation as a whole.

\section{Capital Requirements and Bank Levies}

Capital requirements for banks have been at the heart of the regulatory system right from the start of the financial crisis (and even before that). When we look at the evolution of capital requirements we have to start with the Basel I Accord of 1988. Following the demise of the German Herstatt Bank in 1973, the G10 countries decided to set up the Basel Committee on Banking Supervision which released the Basel I Standard in 1988, prescribing a roughand-ready minimum capital ratio of $8 \%$ of risk-weighted assets after applying hugely simplified risk assessments to certain categories of assets like cash, treasuries, mortgage-backed securities, corporate bonds, shares etc. In 2004, the Basel II accord entered into force, which introduced major refinements to this approach. On the right side of the balance sheet it provided for different capital requirements with reference to "Tier 1" and "Tier 2" capital and on the left side of the balance sheet it established a more individualized system of risk-weighting, e.g. by reliance on internal and external credit ratings. As the Basel II system was widely blamed both for not having prevented the financial

Sven Langedijk/Gaetan Nicodème/Andrea Pagano/Alessandro Rossi, Debt Bias in Corporate Taxation and the Costs of Banking Crises in the EU, European Commission Taxation Papers, Working Paper 50-2014, 2014; skeptical Edgar supra note 30, p.394 et seq., 414; for a full account of the debt/equity distinction from the legal perspective see: Wolfgang Schön et al., Debt and Equity in Domestic and International Tax Law - A Comparative Policy Analysis. In: British Tax Review (2014) p.146-217.

49 Supra note 32, para 2, page 14.

50 IMF supra note 13, Appendix 6 p.64 et seq.; Ruud de Mooij/Gaetan Nicodème, Taxation and Regulation of the Financial Sector, in: Ruud de Mooij/Gaetan Nicodème (Ed.), Taxation and Regulation of the Financial Sector (MIT) 2014, p.1-22 (at p.3); for a general analysis see: Robin Boadway/Michael Keen, Theoretical Perspectives on the Taxation of Capital Income and Financial Services, in: Patrick Honohan (Ed.), Taxation of Financial Intermediation: Theory and Practice for Emerging Economies (World Bank/OUP), 2003, p.31-80 (at p.59 et seq.); Peter Merrill, VAT Treatment of the Financial Sector, The VAT Reader, 2011, p.163-185. 
crisis in the first place and in the second place for having accelerated the financial crisis by enforcing "fire sales" by banks, the Basel Committee looked for better solutions and came up with the Basel III accord of $2009^{51}$. This accord, implemented within the European Union under the Capital Requirements Regulation ${ }^{52}$ and the CRD IV Directive ${ }^{53}$ in 2013, does not only lift the risk-weighted capital ratios for common equity, Tier 1 and Tier 2 capital, substantially, it also introduces a non-risk dependent leverage minimum ratio of $3 \%$ for all credit institutions. On top of these interlinked safety cushions, banks which are of systemic relevance at a global level (so-called G-SIBs) have to provide even higher capital ratios for macro-prudential purposes ${ }^{54}$ following the recent findings of the Financial Stability Board ${ }^{55}$ and the conclusions of the G20 summit ${ }^{56}$ in Antalya in November 2015. The so-called "loss absorbing capacity" of these very large financial institutions is meant to rise to nearly 20 $\%$ of assets in future years.

These capital requirements under banking law can be regarded as the primary instrument of creditor protection for financial institutions - and at the same time they are meant to suppress excessive risk taking leading to bail-outs by governments as shareholders are forced to have substantial "skin in the game" ${ }^{57}$.

Nevertheless, both at the European level and at the German level, there is a parallel route of creditor protection taken under tax law: the bank levy ${ }^{58}$. It was introduced in 2010 by the federal legislator for all German credit institutions (apart from a small sample of special-purpose public banks) ${ }^{59}$ and in 2014 the European legislator created a similar bank levy for the Euro area ${ }^{60}$. But does this make sense? In its latest report on the implementation of the Basel III accord, the Financial Stability Board explained that the mandated increase in

51 Basel Committee on Banking Supervision supra note 1 (2010) para 7 et seq.

52 Supra note 4.

53 Supra note 5.

54 For an overview see: Stijn Claessens, An Overview of Macroprudential Policy Tools, IMF Working Paper (WP/14/214), 2014.

55 Financial Stability Board, Implementation and Effects of the G20 financial regulatory reforms: Report of the Financial Stability Board to G20 Leaders, 9th November 2015, chapter 3.2 ("Implementation Status: Ending too-big-to-fail”).

56 G20 Leaders' Communiqué, Antalya Summit, 15-16 November 2015, para 13.

$57 I M F$ supra note 13, Appendix 3, p.53; Anat Admati/Martin Hellwig, The Bankers' new Clothes: What's Wrong with Banking and What to Do about it? (Princeton University Press) 2013, p.81 et seq.

58 A similar proposal for the U.S. has been raised by Masur/Posner supra note 24 p.129 et seq.

59 Wolfgang Schön/Alexander Hellgardt/Christine Osterlob-Konrad, Bankenabgabe und Verfassungsrecht, 64 Wertpapier-Mitteilungen (2010) p.2145-2157.

60 Supra note 6. 
regulatory capital over the next years is expected to be financed largely from retained earnings and not from additional outside funding ${ }^{61}$. Against this background, an additional tax on the balance sheet seems to undermine the efforts of improving the capital ratio. Any Euro spent on the bank levy cannot be spent on lowering the leverage of the bank at the same time. Are these apparently conflicting policies part of a convincing overall framework?

This would clearly not be the case if the money raised via the bank levy simply went into the general budget of a state. This happened with the temporary bank levy raised by the United States in 2009 - 2010, which was dedicated to making up in retrospect for the public outlays supporting the financial sector during the financial crisis ${ }^{62}$. Such a backward-looking bank levy carries mainly a fiscal purpose and to a certain extent also a distributive purpose, as the "wrongdoers" are visibly forced to pay their "fair share" for the financial mess cleaned up by the government. From a policy point of view, the judgment is not very different for a permanent bank levy paid to the general budget like the UK bank levy, which was introduced in 2009 on an annual basis ${ }^{63}$. While there may be some political agreement to regard this bank levy as a quid pro quo for future bail-outs, there is no legal requirement for the United Kingdom to act accordingly or to reserve dedicated funds for this purpose. Rather, the money disappears in the annual budget and time will show whether and to what extent any future government is willing to spend public money on a future bank crash. In his recent contribution to the Oxford Handbook of Financial Regulation, John Armour explicitly emphasizes the sovereign role of the British Parliament in any future bailout ${ }^{64}$. Against this background it sounds sensible that the UK government has recently announced that from 2016 on the bank levy will be cut by half while a new special tax on banks' profits will be introduced ${ }^{65}$.

The real question is brought up when you try to assess the German and the European system of a bank levy designated to provide financing for a special resolution fund, which will give relief to the general budget in later bailouts. Within such a framework the regulatory capital requirement and the bank levy do not contradict each other necessarily - they rather complement each other.

61 Financial Stability Board supra note 55, para 4.1 ("Building a more resilient financial system").

$62 I M F$ supra note 13, para 11; for a critical view on retributive taxation of the financial sector see: Devereux supra note 17, p.35 et seq.; Shackelford/Shaviro/Slemrod supra note 24 , p.784 et seq.

63 Devereux supra note 14, p.33 et seq.

64 John Armour, Making Bank Resolution Credible, in: Niamb Moloney/Eilís Ferran/ Jennifer Payne, The Oxford Handbook of Financial Regulation (OUP 2016) p.453486 (at p.479).

65 Supra note 19 
When a bank is hit by a crisis, the regulatory capital will provide a first-level cushion to safeguard creditors up to a certain limit. Once the capital is wiped out and the bank falls into bankruptcy, the creditors will get access to the resolution fund set up within a given jurisdiction - or (following European legislation) within the Eurozone at large. The shareholders and the management will have lost their control rights by then and the resolution procedure under the European resolution regime will cut its own path. The policy question for the interaction of capital requirements and bank levies therefore has to be reformulated: Is the overall level of protection administered by these tools adequate and is the division of labor between the two instruments correctly handled?

The first question leads us to the never-ending debate on the "right" level of creditor protection within the European (and global) banking sector. It is well known that no consensus on the adequate level of creditor protection has emerged from the debate - neither in the political nor in the academic arena. On the one hand, Anat Admati and Martin Hellwig have shown convincingly that low capital ratios cannot be defended by the mere partisan interest of shareholders in maintaining high leverage and high returns to capital ${ }^{66}$. Banks had and have to be forced to raise the capital ratio even if existing bank shares lose value on the stock exchange. On the other hand, no one would prescribe $100 \%$ equity financing for banks simply in order to exclude the remote possibility of creditors getting bailed out by the state. What's more: The range of possible investors in the market for bank capital will show a wide variety of risk profiles, some of them preferring profit-dependent equity shares, others preferring fixed-income debentures. If the market for bank finance is meant to work efficiently it has to cater to both constituencies and capital requirements cannot go up indefinitely. If we allow the banking business to accept debt capital, creditor risk cannot and should not be excluded for good, as the social value of the banking sector lies in financing the real economy where innovation risk, production risk, market risk, political risk and many other risks are the lifeblood of the economy itself and will inevitably lead to individual companies (including financial institutions) having to exit the market due to mismanagement or simply bad luck ${ }^{67}$. In the end, the most efficient regulatory setting is not clear and it is with great mistrust that one finds under the heading of the coming "Capital Markets Union" and the accompanying consultation process the European Commission proposing a new era of more lenient capital requirements just in order to fuel the economy ${ }^{68}$.

All we can say at the end of the day is that a higher capital ratio increases the cushion for creditors, thus making bankruptcy and bailout gradually less

66 Admati/Hellwig supra note 57, p.100 et seq.

$67 I M F$ supra note 13, para 14; Chaudry/Mullineux/Agarwal supra note 29, p.18 et seq.

68 European Commission supra note 32, para 3.1. and 5. 
likely and less harmful. When we look at the bailout risk as a proxy for the social costs done to the economy at large, there is simply a slowly upwardsloping curve showing that every increase in the capital ratio will reduce gradually the risk of a future bail-out funded from the general budget.

What does this mean for the choice between capital requirements and a bank tax? It means in the first place that we do not see a dramatic "kink" in the curvature of the cost function which makes it necessary to establish clear-cut prohibitions when a certain level of indebtedness (or "interconnectedness") has been reached ${ }^{69}$. Such a slowly upward-sloping curve can be addressed both by a capital ratio and by a bank levy ${ }^{70}$. But for the design of such a tax the information problem strikes again:

- In the first place, it is unclear what level the levy should have in order to set a calibrated disincentive against excessive risk-taking. While some proposals have tried to identify a measure for excessive risk-taking based on co-variance of risk ${ }^{71}$, legislation in most countries simply tries to approximate the level of risk by applying a (progressive) tax rate to the size of a bank's liabilities ${ }^{72}$.

- Secondly, we do not have any idea beforehand what level the levy should have to provide appropriate funds for a possible resolution required several years later ${ }^{73}$. It might naturally well be that the two numbers do not coincide: the ex ante policy of making risk-taking more costly might lead to an optimal bank tax completely different from the bank tax you need for full and irredundant compensation for bank creditors ex post ${ }^{74}$.

69 A different view is taken by Edgar (supra note 30, p.413) who denotes a point where "the level of risk-taking goes from the imposition of only potential social costs to the imposition of actual costs as an institution becomes insolvent". This may be right from an ex post perspective but from an ex ante viewpoint it is not clear whether and where exists a "tilting point" so that the rise in risky activities cannot be captured by a linear or slowly progressive bank tax (concurring Hellgardt supra note 30, at p.167).

70 A preference for a tax is expressed by Perotti/Suarez supra note 29 (at p.19 et seq.), if the externality is driven by risk and credit quality, while liquidity requirements are preferred, if the externality is driven by "gambles" undertaken by individual players; if both scenarios have to be addressed, a combination of regulatory and tax instruments looks like the dominant solution (at p.37).

71 Tobias Adrian/Markus K. Brunnermeier, CoVaR, NBER Working Paper 17454, 2011.

$72 I M F$ supra note 13, para 21 and p.17 Box 3; Shackelford/Shaviro/Slemrod supra note 24, p.794 et seq. and p.798 et seq.; Garbarino/Allevato supra note 24, p.620 et seq.; for the recently introduced EU-wide contribution see: OrszhagovalMiskova supra note 15, p.15 et seq.

73 Edgar supra note 30, p.417 et seq.

74 Devereux supra note 17, p.39; Edgar supra note 30, p.419 et seq. 
It is exactly this lack of information, which renders a policy mix attractive. If we do not know where the optimal funding ratio has to be set and if we do not have any meaningful take at the amount of revenue to be generated by the bank tax it seems sensible for the legislator to place your bets on more than one horse and to introduce not only a set of regulatory requirements for loss absorption capacity and liquidity which have to be met simultaneously as under Basel III but also a banking tax which ensures an additional layer of protection for creditors ${ }^{75}$. In this picture, the bank tax does not contradict the regulatory goals of the capital requirements. It rather works as an add-on to traditional capital requirements, reserving additional funding for creditor protection.

This leads to the search for an efficient division of labor between the capital requirements and the bank levy given a certain level of own funding: The question runs as follows: Shall the larger part of the shareholders' contributions (or retained earnings) remain under the control of the management of the individual bank (then one should increase the capital ratio) or shall it be administered by the executive board of the resolution fund, thus kept apart from the assets of individual banks (then one should increase the bank tax)? This has to be assessed on the basis of three factors: market expectations as to the impact of the resolution fund on future bail-outs, the respective investment policy ${ }^{76}$ and the "pooling effect" of the resolution fund.

- As far as the impact of regulatory and fiscal measures on "beliefs" resulting in risk-taking incentives are concerned, Shackelford/Shaviro/Slemrod have raised the question whether contributions to a dedicated fund as opposed to a banking tax (which is simply paid to the general budget of the State) will shape the behavior of market participants. They put forward the argument that this clearly defined fund might "effectively constrain the size of future bailouts" 77 as opposed to a general expectation that the State will open its unlimited purse. But this assumption might be unrealistic, given the fact that "governments tend to get drawn into large-scale bailouts, the anticipation of which can distort ex-ante risk-taking incentives." 78 It is not clear why and to what extent the existence of the fund will put that pressure off the back of the State for good.

$75 I M F$ supra note 13, Appendix 3, p.51; Keen supra note 13, p.23 et seq.

76 Reint Gropp, Taxes, Banks, and Financial Stability, in: Ruud de Mooij/Gaetan Nicodème (Ed.), Regulation and Taxation of the Financial Sector (MIT Press) 2014, p.55-65 (at p.63): "The exact nature of the investment may determine the overall success of the measure".

77 Shackelford/Shaviro/Slemrod supra note 24, p.799.

78 Brian Coulter/Colin Mayer/John Vickers, Taxation and Regulation of Banks to Manage Systemic Risk, in: Ruud de Mooij/Gaetan Nicodème (Ed.), Regulation and Taxation of the Financial Sector (MIT Press) 2014, p.67-88 (at p.68). 
- With regard to the investment policy a higher capital ratio seems to be superior to a bank levy. Under the European Regulation establishing a Single Resolution Fund, the administrators are obliged to invest the amounts held in the fund "in obligations of the Member States or intergovernmental organizations, or in highly liquid assets of high creditworthiness (...). Investments shall be sufficiently sectorally, geographically and proportionally diversified"79. Similar rules apply to national resolution funds like in Germany for the "Restrukturierungsfonds". A bank levy therefore entails a temporary transfer of private money to the general budgets of the countries participating in the fund. Contrary to this, private assets acquired out of equity by the bank's managers reflect a marketguided investment decision made by the managers on behalf of the shareholders, thus participating in the risky world of the real economy and contributing to overall economic growth outside the public sector. As long as we accept the underlying assumption that investment in the private sector is superior to investment in the public sector ${ }^{80}$, a higher capital ratio will trump a higher bank levy.

- The assessment might be a different one with regard to the "pooling effect" of the resolution fund. At first sight, any jointly administrated resolution fund seems to offer the benefits of an insurance contract, spreading risk among the industry in order to bail-out individual companies in distress ${ }^{81}$. Moreover, due to the "pooling effect" such a fund would require less overall reserves than "decentralized" capital requirements ${ }^{82}$. But as Brian Coulter, Colin Mayer and Jon Vickers have argued in a recent article, the economics of insurance only apply when we set up a device against asymmetric hits towards otherwise unrelated institutions ${ }^{83}$. The problem with systemic risk in the banking sector lies rather in the symmetric effect of macro-economic shocks like the financial crisis of 2007/08 or the following Sovereign Debt Crisis in the Eurozone, which both hit the whole market with one wide-sweeping stroke. Here the information problem haunts us

79 Art. 75 par.3 supra note 6.

80 This, of course, is subject to the influence of political economy pressures from politicians or the general public (James M. Buchanan/Gordon Tullock, Polluters' Profits and Political Response: Direct Controls Versus Taxes, 65 American Economic Review (1975) p.139-147 (at p.142 et seq.).

81 Edgar supra note 30, p.416; Garbarino/Allevato supra note 24, p.624.

82 Chandry/Mullineux/Agarwal supra note 29, p.17 et seq.; Coulter/Mayer/Vickers supra note 80 , p.82.

83 Coulter/Mayer/Vickers supra note 80, p.68; Giuseppina Cannas et al. (Financial Activities Taxes, Bank Levies and Systemic Risk, European Commission Taxation Papers, Working Paper 43-2014, 2014) have shown that the optimal design of bank levies depends on the question whether the fund is meant to address individual failure of institutions or contagion risk within the market. 
again: It cannot be said in advance whether the resolution fund will rather be needed for an individual collapse or for a wide-reaching recapitalization of the market in general; therefore it makes sense to introduce some insurance element to the overall design.

- Last but not least, the "pooling effect" shows another feature, which can be useful from a regulatory point of view. Once a bank is on the brink of failure with capital largely wiped out and no easy exit route on the horizon, management (and shareholders) might react in an "endgame" sort of fashion, leaving the regulatory framework behind and betting the whole company "on behalf" of the creditors. Under private law, this clear breach both of supervisory and contractual obligations will only bring about damage claims against the involved managers and shareholders which are largely worthless, and any sanctions under administrative law or criminal law will not help the creditors expost as well. In such a situation a pile-up of ex ante payments to a resolution fund shall provide at least some compensation to the creditors. This makes it advisable to combine capital requirements under supervisory law with a limited bank levy funding a resolution regime - this is the world we live in today.

\section{Executive Pay and Bonus Taxation}

The second topic where regulation and taxation interact in the area of financial markets is executive pay. There are two major trajectories to follow: the procedural and substantive limitations set by the provisions on corporate governance for banks ${ }^{84}$ and the recurring proposal of a "bonus tax" on bankers' compensation $^{85}$. Both aim at reducing the incentive to assume excessive risk on behalf of the company which works to the detriment of creditors' claims against the company.

The rules on corporate governance for banking institutions are fundamentally shaped by a double-layer of conflicts between principals and agents. In the first place, the standard conflict between shareholders and management comes to the fore. Shareholders do not command the resources to fully observe and

84 Lucian A. Bebchuk/Holger Spamann, Regulating Bankers' Pay, 98 Georgetown Law Journal (2010) p.247-287; Guido Ferrarini/Niamb Moloney/Maria-Cristina Ungurea$n u$, Executive Remuneration in Crisis: A Critical Assessment of Reforms in Europe, 10 Journal of Corporate Law Studies (2010) p.73-118; Guido Ferrarini/Maria Cristina Ungureanu, Bankers' Pay after the 2008 Crisis: Regulatory Reform in the US and the EU, Zeitschrift für Bankrecht und Bankwirtschaft (2011) p.418-430; Peter Yeoh, Regulating Executive Remuneration in Anglo-American Economies, 36 Business Law Review (2015) p.169-175.

85 Supra note $18-19$. 
evaluate the efforts of the directors and officers of their corporation, therefore one needs either statutory or contractual constraints to monitor the behavior of the agent and to ensure that business activities aim both at enhancing shareholder value and at compliance with the legal framework the company operates in. In this context, the principal agent conflict asks for a management compensation scheme, which aligns interest of the corporate officers and directors with the interest of the shareholders. This is all well researched from a contract design perspective ${ }^{86}$ and has gained traction among legislators around the world.

This principal agent conflict addressed under general corporate law is superseded by a second principal agent conflict when financial institutions are involved $^{87}$. As far as banks are concerned, the bank as such - jointly comprising shareholders and managers - acts as a trustee for creditors financing the activities of the bank to a large extent. Insofar as managers and shareholders jointly take excessive risk, they take that risk on behalf of the creditors. In a fully efficient market, creditors would take care of this possible outcome and ask for corresponding collateral or demand higher interest rates. But given the myopic nature of bank creditors and the general perspective of a government bailout, creditors tend to be content with lower interest rates and do not press for additional governance strings to be attached. This in turn leads to excess profits on the side of the bank which both shareholders and managers will share between them: shareholders get higher dividends, bankers get higher bonuses ${ }^{88}$. Against this background legislative developments around the globe - within the ambit of the G20 and their Financial Stability Board ${ }^{89}$, the European Union and the Federal Republic of Germany - have created in recent years what Klaus Hopt aptly has called a framework of "debtholder governance" ${ }^{90}$, meaning a set of rules for boards and managers which aims specifically at securing the rights of debtholders in addition to the mainstream set of rules benefitting shareholders under general corporate law.

86 Reinier Kraakman et al., The Anatomy of Corporate Law, 2nd Ed. (OUP) 2009, chapters 2 and 3; for recent quasi-experimental evidence on the impact of EU regulation see: Johannes Sauset/Phillip Waller/Michael Wolff, CEO Contract Design Regulation and Risk-Taking, 24 European Accounting Review (2015) p.685-725.

87 Bebchuk/Spamann supra note 84, p.255 et seq.; Hopt supra note 10, p.240 et seq.

88 Vieri Ceriani/Stefano Manestra/Giacomo Ricotti/Alessandra Sanelli, The Role of Taxes in Compensation Schemes and Structured Finance, in: Julian S. Alworth/Giampaolo Arachi (Ed.), Taxation and the Financial Crisis (OUP) 2012, p.88-115 (at p.89 et seq.); for a skeptical view of the role of managers' compensation in the run-up to the financial crisis see: Ferrarini/Ungureanu supra note 84 , p.418 et seq.

89 Financial Stability Board supra note 55, chapter 3.1. (Implementation Status: Building resilient financial institutions); Basel Committee on Banking Supervision, Guidelines: Corporate Governance for Banks, 2015, Principle 11 (Compensation).

90 Hopt supra note 10, p.243. 
Again, the CRD IV Directive ${ }^{91}$ highlights the prominent features of the new rules: firstly, profit-dependent salaries shall relate to long-term profitability and shall not be distorted by short-termism. The European initiatives have pushed national legislators to provide for multi-year deferral of substantial parts of executive compensation and even for a clawback of bonus payments in case of adverse developments. Secondly, profit-dependent compensation must not exceed a given portion of the fixed compensation, reducing the incentives on the side of the managers to take huge risk on behalf of the company in order to benefit strongly from a personal bet on the positive outcome.

It is clear that this set of rules will not be able to fully eradicate perverse incentives on the side of managers. The big point to start with is the overall size of the managers' compensation. As long as there is no fixed ceiling for the compensation package (like in Germany for banks living on public money), any decrease in the manager's profit participation might be balanced out by a rise in fixed salaries ${ }^{92}$. But fixed salaries have their own drawbacks as has been shown for ages in the general principal agent literature - they are granted without paying any respect to the actual performance of the manager in question and they might inflict damage on shareholders. Last but not least the information problem mentioned in the introductory part comes up: As long as we cannot identify the "first-best" salary package to be offered to a given director or officer, we have to choose between either rather loose and vague language aiming at the "adequacy" and "reasonableness" of the compensation package or we put together a set of rather formal rules on procedure (e. g. on board competence or shareholders' "say on pay") and on the ratio between fixed income and variable income which will never fully meet the expectations.

Does the law of taxation offer any help? On the high point of the financial crisis, several countries including the United Kingdom ${ }^{93}$ and France ${ }^{94}$ have temporarily introduced special charges on bonus payments for bank manag-

91 Supra note 5; Jens-Hinrich Binder, The Banking Union and the Governance of Credit Institutions: A Legal Perspective, 16 European Business Law Review (2015) p.467-490 (at p.483 et seq.); Jad Nader/Meliba Dacic, Regulation of Remuneration Policies in the Financial Sector, 57 Bulletin Droit et Banque (2015) issue 12, p.35-49; as to previous EU reforms in this area see Ferrarini/Ungureanu supra note 84, p.424 et seq.; recent empirical work on the effects of these provisions shows mixed results: Jörg-Markus Hitz/ Stephanie Müller-Bloch, Market Reactions to the Regulation of Executive Compensation, 24 European Accounting Review (2015) p.659-684;

92 This is exactly what happened in recent years, see: European Banking Authority, EBA Report: Benchmarking of Remuneration Practices at the European Union Level and Date on High Earners (Data as of End 2014), EBA-OP-2016-05.

93 Supra note 19.

94 Supra note 18. 
ers. Italy still has this bonus tax in place ${ }^{95}$. In Germany it was discussed and rejected - albeit for corporate managers in general ${ }^{96}$. The rationale behind this kind of taxation, which goes beyond the simple application of the general income tax rate to high-end salaries, is related to excessive risk-taking again ${ }^{97}$. Under the assumption that the prospect of a government bail-out incentivizes creditors to agree to low interest rates, thus making it easy for the bank to assume high risks, the bank will make excess profits in the upside situation and hand over corresponding losses to the state budget in the downside situation ${ }^{98}$. This has led the IMF to propose a (Pigouvian) corrective tax, the "financial activities tax" (FAT) covering both the excess profits of the bank (and its shareholders) itself and the excess salaries handed out to the managers ${ }^{99}$.

Again one might ask whether from a regulatory point of view it makes sense to introduce that sort of tax - either as a substitute for corporate governance mechanisms or as a complement to substantive limitations - like the bank levy in relation to the capital requirements. On the face of it there is one big benefit and one big drawback. The benefit lies in the fact that the impact of any bonus tax will be broad and it will be hard to circumvent its application. The same holds true for tax provisions which restrict the deductibility of executive pay when the bank's taxable profit has to be assessed. Moreover, any increase in the overall compensation package will lead to a higher tax (and one might even think of a progressive scale to render such increases economically less attractive). On the other hand it is evident that any meaningful measurement of excess profits or excess bonuses is extremely hard to implement ${ }^{100}$. In the first place one has to make a counterfactual comparison between the bank's profits (and the bankers' bonuses) in the undistorted situation and the profits in the situation shaped by the bail-out prospect. This might be traced back to a fictitious interest gap between distorted and undistorted interest rates for debt capital granted by outsiders to the bank ${ }^{101}$. As a second step one would have to take account of competition among banks - as they all benefit from this sub-

95 Supra note 18.

96 Supra note 18.

97 Michael Hilmer, Bailouts, Bonuses and Bankers' Short Termism, Max Planck Institute for Tax Law and Public Finance Working Paper 2014 - 17; Michael Hilmer, Too Many to Fail - How Bonus Taxation Prevents Gambling for Bailouts, Max Planck Institute for Tax Law and Public Finance Working Paper 2014 - 18.

98 Timothy Besley/Maitreesh Ghatak, Bailouts and the Optimal Taxation of Bonus Pay, 103 American Economic Review: Papers \& Proceedings (2013) p.163-167; Timothy Besley/Maitreesh Ghatak, Taxation and Regulation of Bonus Pay, LSE STICERD Research Paper No. EOPP 030, 2011.

$99 I M F$ supra note 13 , para 32 et seq.

$100 I M F$ supra note 13, para 36 Box 6; Edgar supra note 30, p.426; Shackelford/Slemrod/ Shaviro supra note 24 , p.797 et seq.

101 Garbarino/Allevato supra note 24, p.625. 
sidy, it is easily possible that they pass it on to their customers, a strategy that would eradicate the economic rent from their own profit and loss account ${ }^{102}$. Last not least one would have to distinguish between excessive salaries which are due to the "classical" principal agent conflict observed in many industries and the "special" conflict of interest under "debtholder governance" (to borrow again Klaus Hopt's helpful definition).

But the biggest problem for any tax which is meant to constrain excess salaries is the incidence of the tax. As long as under corporate governance rules there is no upper ceiling for bankers' compensation, any extra tax on bonuses can easily be offset economically by an increase in bonus payments. The same holds true if non-deductibility of these payments does not lead to a reduction in size. The story of the U.S. tax treatment of stock options is a telling one ${ }^{103}$. Back in 1980 the U.S. Congress enacted a tax provision, which prohibited the deductibility of any fixed executive compensation payment beyond one million dollars per year. The reason behind this move was the perception that contracts providing for high fixed income did not meet the criteria of good governance, as the aim of aligning the interests between managers and shareholders was not fulfilled. Under the new framework, managers were invited to show that profits had risen due to or at least during their time in office. This extra tax burden on fixed salaries set free the issuing of stock options and similar profit-related compensation packages. In the end, the overall compensation of corporate managers in the United States rose to levels unseen before. Also in the United Kingdom, bonus taxation of bankers led to an increase in overall salaries (and to the relocation of banking business to Switzerland for a limited time period $)^{104}$.

To put it differently: Tax only works as an additional corrective if the regulator really bites in the first place and sets hard and fast limitations to overall compensation. Otherwise, any additional tax will largely be shifted towards the shareholders or towards the customers by a simple increase in salary ${ }^{105}$. But

102 Although empirical evidence is scarce, a review of the literature has shown that banks are able to pass on taxes to their customers (Copenhagen Economics, Elasticities of Financial Instruments, Profits and Remuneration, European Commission Taxation Papers, Working Paper 30-2012, para 3.2, p.29); most writers assume that bank employees will be able to capture this rent due to the scarcity of human capital in this field (Edgar supra note 30, p.422 et seq.; Besley/Ghatak supra note 98 (2011) p.3).

103 Arne Friese/Simon Link/Stefan Mayer, Taxation and Corporate Governance - the State of the Art, in: Wolfgang Schön (Ed.), Tax and Corporate Governance (Springer) 2008, p.375-425 (at p.389 et seq.).

104 Julian S. Alworth/Giampaolo Arachi, Introduction, in: Julian S. Alworth/Giampaolo Arachi (Ed.), Taxation and the Financial Crisis (OUP) 2012, p.1-27 (at p.12 et seq.).

105 Doina Radulescu, The Effects of a Bonus Tax on Manager Compensation and Welfare, in: 68 FinanzArchiv/Public Finance Analysis (2010) p.1-16. 
at this point you can also turn the argument upside down: If executive pay is sensibly constrained under "debtholder governance", i.e. if the compensation package does not give rise to an incentive for managers to take on excessive risk, it does not make sense to put an extra layer of tax on top of it ${ }^{106}$ - at least if it goes beyond the progressive scale of the income tax which has to be applied anyway. A "bonus tax" proposed simply for redistributive reasons ${ }^{107}$ would require substantial additional justification in the light of the overall income tax framework.

\section{Regulating and Taxing Financial Transactions}

Currently, the most debated issue between regulation and taxation of financial markets is the proposal of a "Financial Transactions Tax" which has been floated in 2011 at the level of the European Union ${ }^{108}$ and which is still under review for implementation by "enhanced cooperation"109. It is very clear that the FTT seems to have a lot of appeal for lawmakers as it is meant to raise enormous revenue for the states - if the scope is broad enough and if the rate is high enough ${ }^{110}$. Politicians praise it as a major contribution of the financial sector to the common good. Moreover it is meant to set a disincentive to excessive speculation ${ }^{111}$, in particular high-frequency trading which is blamed for a lot of dysfunctions in the financial markets ${ }^{112}$. But does it make sense to apply this wide-reaching tax against the background of extensive and substantive supervisory regulation of financial markets? Since the financial crisis, the European Union and national legislators have not been passive when it comes to targeted responses to deficiencies of financial markets. Substantial elements of this major effort include the renovation or introduction of the "Markets in Financial Instruments Directive" (MiFID II) ${ }^{113}$, the "Market Abuse Regula-

106 Edgar supra note 30, p.426 et seq.

107 Besley/Ghatak (2011) supra note 97, p.20 et seq.; Edgar supra note 30, p.426 et seq.

108 Supra note 21; a similar proposal for the U.S. under existing regulatory authority has been put forward by Masur/Posner supra note 24 p.131 et seq.

109 Supra note 22.

110 Shackelford/Shaviro/Slemrod supra note 24, p.796 et seq.

111 Joseph E. Stiglitz, Using Tax Policy to Curb Spectulative Short-Term Trading, 3 Journal of Financial Services Research (1989) p.101-115.

112 Jonathan Fisher/Anita Clifford/Freya Dinshaw/Nicholas Werle, Criminal Forms of high frequency trading on the financial markets, 9 Law and Financial Markets Review (2015) p.113 -119; a balanced view on the negative externalities of modern trading structures is taken by Merritt B. Fox/Lawrence R. Glosten/Gabriel V.Rauterberg, The New Stock Market: Sense and Nonsense, 65 Duke Law Journal (2015) p.191-277.

113 Directive 2014/65/EU of the European Parliament and of the Council of $15^{\text {th }}$ May 2014 on markets in financial instruments and amending Directive 2002/92/ED and Directive 2011/61/EU, O.J. L 173 of $12^{\text {th }}$ June 2014, p.349 et seq. 
tion"114, the "European Market Infrastructure Regulation" (EMIR) ${ }^{115}$, the delegated regulation on short selling 116 and many more legislative packages which are meant to separate beneficial market transactions from harmful market transactions.

While this regulatory legislation shows a high degree of sophistication separating the good deals from the bad deals, the FTT would tax all transactions alike, thus drowning the financial sector in a hot bath of muddy water. The fiscal burden under the FTT does not depend at all on a qualitative assessment of a financial transaction; it simply rises in proportion to the sheer quantity of financial transactions $s^{117}$. From the perspective of an efficient corrective tax this leads to the question whether the harm done to the financial markets is correlated to the number of transactions performed by a taxpayer. Basically, this is not the case. To the contrary: a high number of transactions signals the existence of a deep and liquid market and it contributes to a reduction of the bidask spread for financial instruments ${ }^{118}$. When we apply the test formulated above it cannot be said that the social costs of financial transactions incrementally rise with the quantitative size of these events. Taxation seems to be exactly the wrong instrument to fight abusive behavior. The one and only example which is invoked by proponents of the FTT is high-frequency trading which some regard as socially wasteful and thus the right target for a corrective tax simply based on the number of transactions. But again the case is not so clear ${ }^{119}$. There exist some questionable techniques of high-frequency trading like the market-manipulating efforts described in Michael Lewis' bestseller on the Flashboys who employed enormously fast electronic signals to intentionally distort demand and supply in proprietary markets ${ }^{120}$. But these techniques are better addressed under a qualitative approach which prohibits certain

114 Regulation (EU) No.596/2014 of the European Parliament and of the Council of 16 April 2014 on market abuse (market abuse regulation) and repealing Directive 2003/6/ EC of the European Parliament and of the Council and Commission Directives 2003/ 124/EC, 2003/125/EC and 2004/72/EC, O.J. L 173 of 12th June 2014, p.1 et seq.

115 Regulation (EU) No.648/2012 of the European Parliament and of the Council of 4 July 2012 on OTC derivatives, central counterparties and trade repositories, O.J. L 201 v. 27.7.2012, S. 1 et seq.

116 Regulation (EU) No. 236/2012 of the European Parliament and of the Council of 14 March 2012 on short selling and certain aspects of credit default swaps, O. J. L 86 of 24th March 2012, p.1 et seq.

$117 I M F$ supra note 13, para 30 and Box 5; Hemmelgarn/Nicodème supra note 17, p.131 et seq.; Wolfgang Schön, Die Finanztransaktionssteuer - ein "fairer Beitrag” des Finanzsektors? 176 Zeitschrift für das gesamte Handels- und Wirtschaftsrecht (2012) p.261267.

118 Garbarino/Allevato supra note 24, p.630 et seq.

119 Fox/Glosten/Rauterberg supra note 112; Vella supra note 30, at p.182 et seq.

120 Michael Lewis, Flashboys (Norton) 2014. 
behavior and not by a fiscal approach which is not able to distinguish between socially useful and socially wasteful activities ${ }^{121}$.

The case against the FTT becomes even stronger when we recognize that the regulatory technique employed under supervisory law and the quantitative approach chosen under the FTT contradict each other in relevant situations. Two striking examples have been analyzed by Caroline Heber and Christian Sternberg from the Max Planck Institute for Tax Law and Public Finance in Munich in an award-winning paper ${ }^{122}$. The first example concerns over-thecounter trades (OTC trades) in financial derivatives. In the pre-crisis world, financial institutions were entitled to enter into OTC trades simply on a bilateral basis. If we applied the proposed directive on the financial transaction tax to such an OTC trade, each of the involved parties would be liable to tax exactly once. Contrary to this, under the European Market Infrastructure Regulation of 2012 and under the MiFIR-Regulation of 2014, certain trades in financial derivatives are required to be effected through Central Counterparties which can only be approached by special institutions admitted for clearing purposes (so-called "clearing members"). To a large extent, this legislation affects mostly OTC-derivatives as the European Institutions want to reduce counterparty risk and to increase market transparency for OTC trades. From the perspective of the regulatory goal this is perfectly fine. From the perspective of the FTT it entails a multiplication of the number of taxable transactions. Even if we take into account that the Central Counterparty as such is exempt from FTT, neither the clearing members nor the financial institutions triggering the transaction enjoy a similar beneficial treatment under the current draft. The improvement of the regulatory framework by interposing neutral agents leads to a higher tax burden. A similar effect can be perceived with regard to short selling. Under the new Short Selling Regulation market participants are obliged to enter into a hedge transaction before they enter into the sale as such. Depending on the choices made ex post this hedge transaction will have to be modified, canceled or executed. Again, the regulatory goal is fine but the regulatory technique forces market participants to enter into additional financial transactions not required under the old regime. Does it make sense to punish those who comply with the new rules by piling

121 Andreas M. Fleckner, Regulating Trading Practices, in: Eilís Ferran/Niamb Moloney/ Jennifer Payne (Ed.) The Oxford Handbook of Financial Regulation (OUP) 2015, p.596-630 (at p.618).

122 Caroline Heber/Christian Sternberg, Over-the-Counter Derivative Markets in the Light of EMIR Clearing Obligations and the Financial Transaction Tax, Derivatives and Financial Instruments Journal (2014) p.107-116; see also Caroline Heber/Christian Sternberg, Market Infrastructure Regulation and the Financial Transaction Tax, Working Paper of the Max Planck Institute for Tax Law and Public Finance No. 201407. 
several layers of taxation on them? These examples make perfectly clear that taxation of financial transactions is not only superfluous but also dangerous and counterproductive as there is a complete lack of coordination between the regulation and the taxation of the financial sector.

\section{The Political Economy of the Choice between Regulation and Taxation}

This last example paves the way to some concluding thoughts about the political economy of the regulation and the taxation of the financial sector. Political economy does not ask for the most efficient legal regime and rather examines the underlying incentives for politicians, lobby groups and voters to push for a specific piece of legislation. Politicians love corrective taxation as it pretends to steer human behavior in the right direction while at the same time increasing the funds available for politicians to exercise and to keep the power they have. It is evident that one of the foremost incentives for the European Commission to propose the FTT in the first place was the window of opportunity to establish for the first time a dedicated tax at the level of the European Union the revenue of which was meant to flow - at least in part - directly to the European budget ${ }^{123}$. For national politicians, sympathy for the FTT is to a large extent a mixture of symbolic policy ("tax the rich") and budgetary claims. And it does not force them to go into the details of a qualitative assessment of beneficial and wasteful financial activities and to form a meaningful statement on the pros and cons.

But there also exist political economy considerations which rather plead for regulation instead of taxation. Building on previous work by James Buchanan and Gordon Tullock ${ }^{124}$ on environmental legislation, scholars like Alberto Alesina have pointed out that the majority of voters should prefer regulation over taxation ${ }^{125}$. The reason is clear-cut: Regulation is by its very nature limited to some professional actors in the market whose impact in a popular vote is rather small given the size of this constituency in the overall composition of voters. Taxation, on the other hand, shows a tendency to have a broad scope, putting a burden on many individuals and firms even if a progressive scale

123 Supra note 21.

124 Buchanan/Tullock supra note 80.

125 Alberto Alesina/Francesco Passarelli, Regulation versus Taxation, 110 Journal of Public Economics (2014) p.147-156; Donato Masciandaro/Francesco Passarelli, Regulation and Taxation: Economics and Politics, in: Julian S. Alworth/Giampaolo Arachi (Ed.), Taxation and the Financial Crisis (OUP) 2012, p.257-269; Donato Masciandaro/Francesco Passarelli, The Political Economy of Containing Financial Systemic Risk, in: Rund de Mooij/Gaetan Nicodème (Ed.), Taxation and Regulation of the Financial Sector (MIT) 2014, p.115-130. 
might hit some actors harder than others. As most voters want to avoid any regulatory or fiscal burden, they will opt for regulation with a sharp focus on a limited group of market participants. Unless these market participants command strong lobby power, the demands of the voters' majority will be followed by the political institutions.

\section{Conclusions}

In its recently published Action Plan on the Capital Markets Union, the European Commission has named a few haphazard tax items which they regard as obstacles to a fully-fledged capital market union. These include the aforementioned "debt bias"126, the existence of withholding taxes on cross-border dividend and interest payments ${ }^{127}$ as well as the lack of a Europe-wide Common Consolidated Corporate Tax Base ${ }^{128}$. While this list does not seem to build on a deeply informed systematic approach to European Tax Policy it seems odd, that none of the levies discussed in this article (bank levies, bonus taxes, financial transaction taxes) are even mentioned in the Action Plan. One should hope that the Commission will take these instruments into account when they perform the comprehensive review of existing legislation announced in the Action Plan. And we should hope that they will seek guidance in the motto given by Klaus Hopt to such an exercise: "Form follows Function"!

126 European Commission supra note 32, para 2, p.14

127 European Commission supra note 32, para 6.2., p.24

128 European Commission supra note 32, para 2, p.14. 